\title{
IMPASSES DE FORMAÇÃO: PENSAMENTO CONSERVADOR EM SCHWARZ E FREIRE
}

\author{
Silvio Ricardo Gomes Carneiro ${ }^{1}$
}

Resumo: O artigo pretende descrever a gênese do pensamento conservador como fenômeno da formação. Para tanto, considera a crítica literária e a educação como fontes importantes de descrição do sistema de formação nacional. Assim, apresenta a análise do pensamento conservador no ensaio "As ideias fora do lugar" de Roberto Schwarz. O ensaísta reflete aqui a gênese do conservadorismo nacional na figura dos homens livres, fundamentais na obra de Machado de Assis. Trata-se da submissão à ordem dos favores e da composição social dos agregados sob o olhar das elites dominantes. De maneira complementar, a pedagogia de Paulo Freire também ressalta a figura do pensamento conservador, mas do ponto de vista da condição do oprimido. É a partir do momento em que as contradições possibilitam a emersão para a consciência crítica que também opera com mais força o fanatismo apoiado no silenciamento e na violência do conservadorismo. Portanto, tanto sob o olhar do senhor, quanto da massa dos oprimidos, o pensamento conservador são respostas a impasses de formação. Seguimos, ao fim, com a pergunta: como intervir a partir do diagnóstico estético-político e pedagógico descritos, respectivamente, por Schwarz e Freire?

Palavras-chave: Conservadorismo, Sistema de Formação, oprimidos, Roberto Schwarz, Paulo Freire.

\footnotetext{
“Eu cínico, alma sensível? Pela coxa de Diana! esta injúria merecia ser lavada com sangue, se o sangue lavasse alguma coisa nesse mundo. Não, alma sensível, eu não sou cínico, eu fui homem; meu cérebro foi um tablado em que deram peças de todo gênero, o drama sacro, o austero, o piegas, a comédia louçã, a desgrenhada farsa, os autos, as bufonarias, um pandemônio, alma sensível, uma barafunda de coisas e pessoas, em que podias ver tudo, (...) desde o magnífico leito de Cleópatra até o recanto da praia em que o mendigo tirita seu sono."

Machado de Assis, Memórias Póstumas de Brás Cubas
}

Com o intuito de pensar o ato da intervenção em tempos contrarrevolucionários, insisto aqui no debate sobre a formação da experiência intelectual brasileira. Apelo, de início, ao tipo social do pensamento conservador nacional a partir de sua gênese. Com isso, já anuncio uma investigação arriscada que assumo nos primeiros passos: apreender a natureza do pensamento conservador em terra brasilis. A proposta é sugerir uma aproximação ainda pouco explorada entre os dois sistemas de formação centrais para a expressão da dialética nacional: a perspectiva da literatura e da educação. Uma educação

\footnotetext{
1 Professor de Filosofia da Universidade Federal do ABC e coordenador do GT Filosofar e Ensinar a Filosofar da ANPOF.
} 
pela noite, como nomeia Antonio Cândido, quando todos os gatos são pardos, complemento.

Portanto, apresento aqui um ensaio no duplo sentido do termo. Enquanto estilo de pensamento que procura capturar um objeto movediço - como é nosso pensamento conservador; mas também enquanto "experimento", tentativa de formação de um conhecimento. Nesse sentido, compartilho com os leitores esta primeira experiência, cujos efeitos ainda são improváveis.

Em geral, sob a luz da teoria crítica, o pensamento conservador marca um impasse de formação. Palavras progressistas e arcaicas se misturam em momentos cruciais de transformação histórica. A boca conservadora profere palavras de regressão em defesa dos direitos mais avançados. Pela liberdade, menos direitos; pelos direitos, menos liberdade. Um pêndulo ético-político capenga que desloca uma multidão de lutas para configurar a moral lampeduseana: "Se queremos que tudo fique como está, é preciso que tudo mude".

É neste movimento da dialética do mau infinito que lanço aqui uma questão crucial: até que ponto nosso conservador é fruto de certo sistema local de formação? Há vários modos de responder tal inquietação. ${ }^{3}$ Recortaremos aqui dois autores a título de provocar o debate. Eles vêm de campos distintos, como já havia anunciado. Da literatura, ressalto a interpretação de Roberto Schwarz sobre o conservador Brás Cubas. Da educação, a pedagogia do oprimido de Paulo Freire, sobretudo, o momento em que descreve os impasses nos processos de diálogo. Nosso objetivo é entender como se forma o pensamento conservador nas reflexões desses dois autores e, nessa articulação, buscar compreender um pouco mais a máscara desse discurso no cenário nacional (ou periférico) e suas possíveis intervenções.

\section{Ideias fora do lugar}

Podemos afirmar que Schwarz toca no coração conservador à medida em que avança sobre o material literário nacional. Desde as lições de Antonio Cândido, compreende-se a forma literária "imitando" a estrutura social. De tal modo que, como

\footnotetext{
2 LAMPEDUSA, O leopardo, p. 21.

3 V. CHAUI, Brasil: mito fundador e sociedade autoritária. Ou o ensaio "Ornitorrinco" in OLIVEIRA, Crítica à razão dualista. Sem deixar de lado os autores da "formação": CANDIDO, Formação da literatura brasileira; FURTADO, Formação econômica do Brasil, PRADO Jr, Formação do Brasil contemporâneo, ou ainda HOLLANDA, Raizes do Brasil, FERNANDES, A revolução burguesa no Brasil. Sobre a literatura da formação, ver ARANTES, Sentimento da dialética na experiência intelectual brasileira: dialética e dualidade segundo Antonio Candido e Roberto Schwarz. Todos acompanhados de uma vasta literatura sociológica e econômica sobre a formação do Brasil forjada à economia da escravidão. Para um contraponto interessante, ver também o debate mais recente em SOUZA, A tolice da inteligência no Brasil.
} 
afirma Paulo Arantes, "a pedra angular do raciocínio é a noção de forma, princípio mediador responsável pela junção de romance e sociedade". " Não se trata aqui de compreender a literatura como mera "expressão" da sociedade brasileira, mas sim na medida em que responde à questão: "a que país alude a forma de um romance brasileiro?" 5 O exercício de Schwarz sobre o caso Brás Cubas exige uma investigação das formas assumidas pelo romance: a narrativa de um defunto-autor, o estilo fragmentário, o riso cínico para o leitor. Todo um conjunto discursivo em resposta às mediações sociais da experiência nacional.

Interessa aqui, dentre outros ensaios de Schwarz, aquele que denuncia as "ideias fora do lugar". Momento privilegiado em que o crítico descreve o sistema de dualidades nacional que forjava a matéria literária de Brás Cubas. Nela encontramos a classe dos "homens livres" ao lado da dicotomia clássica da formação e reconhecimento periféricos entre mestre e escravo. Entre estes dois últimos, a relação era clara, preenchida por violência e dominação. Mas, e quanto aos ditos "homens livres"? Descreve nosso autor: "Nem proprietários nem proletários, seu acesso à vida social e a seus bens depende materialmente do favor, indireto ou direto, de um grande. O agregado é sua caricatura". ${ }^{6} \mathrm{Da}$ negação desse "nem-nem", a matéria social do pensamento conservador se forja. Temos aqui o "nexo efetivo" que constitui a vida ideológica nacional sob a forma literária. E no favor, como veremos, sua grande moeda de troca.

No caso de Brás Cubas, a aventura se passa pelo defunto-autor que atravessa todas as sutilezas ideológicas. Personificação desse estado metafísico-físico, Brás Cubas, senhor, pendula entre as posições ideológicas várias. Sobretudo por isso, gira ao redor do personagem uma multidão de homens livres. Como no episódio em que encontra o então homem livre, Prudêncio. Este havia sido escravo da família de Brás Cubas que, menino, já mostrava sua face violenta de senhor sobre seu escravo feito cavalo, montando-lhe com rédea e chicote. Anos mais tarde, já adulto, Brás Cubas se depara com um homem submetido aos maus-tratos de seu senhor. Nosso personagem reconhece Prudêncio agora como homem livre castigando seu submisso. Brás Cubas intervém contra a atrocidade pública, quando reconhece a voz de seu moleque Prudêncio nos gritos de "Cala a boca, besta!" Interpelado, este recua de seus atos obedecendo ao "Nhonhô Cubas" e suspende o castigo de seu submisso, não sem deixar de lado o seu lugar de poder. De fato, Nhonhô manda, não pede. E seu escravo maltratado é escorraçado para casa ao mando de Prudêncio: "Entra para casa, bêbado!"’

\footnotetext{
${ }^{4}$ ARANTES, Sentimento da dialética..., p. 42.

5 ARANTES, Sentimento da dialética..., p. 41.

6 SCHWARZ, "As ideias fora do lugar" in SCHWARZ, Ao vencedor as batatas: forma social e processo social nos inícios do romance brasileiro, p. 16.

7 Passagens do capítulo LXVIII, “O Vergalho” in ASSIS, Memórias póstumas de Brás Cubas, p. 79-80.
} 
O episódio de aparente humanismo se dissolve no ar quando lembramos o quanto Prudêncio reproduz a gramática violenta de seus senhores. A "banalidade universalista" do altivo Brás Cubas é contrastada com suas reflexões posteriores. ${ }^{8} \mathrm{Na}$ verdade, reconhece no ato de Prudêncio a reprodução de seus próprios atos violentos. Não remete a um ato de tomada de consciência moral do personagem, apenas mais uma de suas reflexões soltas e caprichosas de senhor que conclui:

Logo que meti mais adentro a faca do raciocínio achei-lhe o miolo gaiato, fino, e até profundo. Era um modo que o Prudêncio tinha de se desfazer das pancadas recebidas - transmitindo-as a outro. Eu, em criança montavao, punha-lhe um freio na boca, e desancava-o sem compaixão; ele gemia e sofria. Agora, porém, que era livre, dispunha de si mesmo, dos braços, das pernas, podia trabalhar, folgar, dormir, desagrilhoado da antiga condição, agora é que ele desbancava: comprou um escravo, e ia-lhe pagando, com alto juro, as quantias que de mim recebera. Vejam as sutilezas do maroto!?

Em tal imersão, nenhuma palavra de remorso moral por parte de Brás Cubas. Pelo contrário, resta um júbilo pelas sutilezas de sua criatura. Prudêncio descontava a brutalidade de seu senhor na reprodução da ordem violenta, agora dirigida contra seu subalterno.

O domínio senhorial de Prudêncio, assim, era tão aparente quanto o humanismo de Brás Cubas. Para Prudêncio, o pedido de Nhonhô é uma ordem, como haveria de ser para a multidão de homens livres sob o olhar de seus senhores. Bastou-lhe aparecer seu verdadeiro senhor, para que as estruturas sociais efetivas fossem reestabelecidas e o nexo ideológico, reforçado. Pois o eixo central a ser compreendido aqui é o modo como os vínculos de reconhecimento operam. E aqui ressalto a natureza do "favor" como a principal mediação da dialética nacional, conforme Roberto Schwarz:

com mil formas e nomes, o favor atravessou e afetou o conjunto da existência nacional, ressalvada sempre a relação produtiva de base, esta assegurada pela força. Esteve presente por toda parte, combinando-se às mais variadas atividades, mais e menos afins dele, como administração, política, indústria, comércio, vida urbana, Corte, etc. Mesmo profissões liberais, como a medicina, ou qualificações operárias, como a tipografia, que, na acepção europeia, não deviam nada a ninguém, entre nós eram

\footnotetext{
8 SCHWARZ, Um mestre na periferia do capitalismo: Machado de Assis, p. 113.

${ }^{9}$ ASSIS, Memórias..., p. 80.
} 
governadas por ele. E assim como o profissional dependia do favor para o exercício da sua profissão, o pequeno proprietário depende dele para a segurança de sua propriedade, e o funcionário para o seu posto. O favor é a nossa mediação quase universal... ${ }^{10}$

É sob a marca do favor que Prudêncio acata o pedido de Nhonhô. O ex-escravo, que em seu íntimo reservara o ódio do oprimido na ordem escravocrata, desloca sua revolta na forma de reprodução do status quo. Acata o pedido de seu ex-senhor e submete seu escravo à humilhação e violência. $\mathrm{O}$ ciclo não se quebra, pelo contrário: é reforçado pelas mais diversas instâncias sociais.

Decerto, a "relação produtiva de base" (a ordem estabelecida entre mestre e escravo) está assegurada. A aparência senhorial de Prudêncio não deixa nada a desejar para a forma violenta com que senhores lidam com seus escravos. Contudo, a aparência senhorial de Prudêncio enquanto homem livre vive sob a moeda dos favores, este vínculo nacional que amalgama as contradições, desloca as revoltas e reproduz a cadeia de submissões na formação nacional. Conforme conclui Schwarz: "O escravismo desmente as ideias liberais; mais insidiosamente o favor, tão incompatível com elas quanto o primeiro, as absorve e as desloca, originando um padrão particular". ${ }^{11}$

Com isso, Schwarz indica dois elementos na configuração ideológica nacional. De um lado, a convivência do escravismo com as ideias liberais; de outro, as relações de favor, também contrárias ao ideário liberal, mas de maneira bem particular: integrando suas contradições formando um sistema unidimensional das relações de poder. ${ }^{12}$ Ambos incompatíveis com o liberalismo - compreendido na estatura moral da autonomia de seus

\footnotetext{
10 SCHWARZ, Ao vencedor as batatas..., p. 16.

11 SCHWARZ, Ao vencedor as batatas..., p. 17.

12 Valho-me aqui da interpretação de Herbert Marcuse em O homem unidimensional: Estudos da ideologia da sociedade industrial avançada. Muito embora Marcuse e Schwarz estejam comentando tempos sociais diferentes (o primeiro, o capitalismo tardio; o segundo, a virada nacional para o republicanismo do XIX), não podemos esquecer que Schwarz faz este retorno para compreender os anos de chumbo, reencontrando no passado histórico algumas das ordens sociais que já antevia com Machado de Assis. Como se a estrutura lógica da formação social nacional apresentasse sua fratura exposta nos golpes desferidos em 1964. Como afirma Paulo Arantes: "Podia então presumir que o juízo sobre o nosso maior escritor [Machado de Assis] alguma coisa ganharia em ser filtrado pela experiência atual do crítico. Era de se esperar que a resposta à pergunta crítica fundamental - o que me diz hoje este autor? - também passasse pela interpretação de um acontecimento que lançava uma luz retrospectiva sobre um largo período da história brasileira. As análises de 64 costumam recuar até 30, mas por que não retroceder até o solo mais original de nossa formação? O golpe não exporia de maneira estridente as fraturas de um país de passado colonial? Ora, em 1964 deu-se de fato um disparate revelador" (ARANTES, Sentimento de dialética..., p. 31, colchetes nossos)
} 
sujeitos - escravismo e relações de favor andam lado a lado na manutenção do status quo, como na dualidade presente em Prudêncio.

Claro, Schwarz não defende aqui o liberalismo como modelo ideal de sociedade. ${ }^{13}$ Interessa-lhe o local das contradições, das quais o ideário liberal não escapa. Nesse sentido, Schwarz não dispensa termos para advertir que "a liberdade do trabalho, a igualdade perante a lei e, de modo geral, o universalismo eram ideologia na Europa também; mas lá correspondiam às aparências, encobrindo o essencial - a exploração do trabalho". ${ }^{14}$ Com isso, sublinha a ideologia europeia enquanto jogo das aparências, que faz do discurso e práticas liberais um mecanismo que encobre a exploração das forças de trabalho. Em nossa periferia do capital, também as ideias seriam falsas, mas num sentido "diverso, por assim dizer, original". ${ }^{15}$ Lugar em que incompatíveis convivem e, nisso, podemos dizer, o pensamento conservador se forja com a matéria local do favor. Isso porque, diante do escravismo, o favor opera de maneira mais insidiosa, ao movimentar o território ideológico sem dissolver antagonismos. Mais do que se atrair, os opostos se integram caprichosamente pelo nexo ideológico quase universal do favor, tornando-os indiferentes ao manejo da dominação.

Com efeito, Schwarz nota que a ideologia local não se manifesta na ordem das aparências, como no ideário europeu, que deixava à sombra a essência violenta das relações. Enquanto no outro lado do Atlântico as contradições se diluíam pela aparência universal dos discursos ideológicos liberais dirigidos para todas as classes, a despeito das divisões sociais, aqui o vínculo ideológico emerge na violência basal das estruturas da reprodução social na ordem dos caprichos. O ideário liberal importado atravessa todo o corpo social nacional, submisso aos movimentos internacionais do capital, chegando aqui sob a chancela dos favores e da violência escrava pelos quais pendulam as razões sociais.

${ }^{13} \mathrm{E}$, neste sentido, talvez não caia nas armadilhas detectadas pela revisão crítica da bibliografia da formação realizada por Jessé Souza em seu $A$ tolice da inteligência do Brasil. Pensando nos desdobramentos do "homem cordial" de Sérgio Buarque, Souza identifica limites de tal paradigma crítico que ainda se serve do espelho europeu para determinar os valores críticos da sociedade nacional. Neste sentido, afirma Souza: "O interessante do argumento de Buarque é que, apesar de o "homem cordial" [herdeiro direto dos favores do homem livre] estar presente em todas as dimensões da vida, sua atenção se concentra apenas na ação do 'homem cordial' no Estado. (...) O mercado capitalista deixa de ser uma instituição ambivalente (...) para ser apenas o reino da 'virtude' por excelência. O Estado, também ambivalente, podendo refletir interesses de todo tipo, sendo ele próprio um campo de lutas intestinas, é 'congelado' ao lado de uma suposta 'elite privilegiada', a qual, como ninguém a define, se refere a todos e a ninguém e pode ser usada em qualquer contexto a bel-prazer do falante (quase sempre, ele próprio, de alguma 'elite')" (SOUZA, $A$ tolice da inteligência no Brasil..., pp. 21-22. Talvez Schwarz escape deste modelo crítico denunciado por Souza, tanto por reconhecer a ordem dos favores entre os homens livres, mas também - ainda que nos pressupostos da crítica vinda da periferia - por compreender que o ideário liberal não deixa de estar imerso nas suas contradições.

14 SCHWARZ, Ao vencedor as batatas..., p. 12.

15 SCHWARZ, Ao vencedor as batatas..., p. 12. 
Nesse sentido, a ideologia local não descreve sequer falsamente a realidade, sua ordem é outra: "é da ordem do relevo social, em detrimento de sua intenção cognitiva e de sistema". ${ }^{16}$ As relações sociais são postas de modo muito claro, como para Prudêncio era essencial saber quem mandava e quem obedecia. Tudo, portanto, estava na possibilidade das brechas abertas pela arbitrariedade do favor. Pois, através dos caprichos concedidos aos favorecidos, era possível se deslocar no interior do campo de forças sociais e, com a moeda dos favores, o agregado acumulava certo diferencial no corpo social e suas redes de relações. Diferencial com o qual sobrevive na permanente ordem de violência e barbárie estampada na formação local.

Aqui o pensamento conservador se apresenta de maneira mais cristalina para Schwarz: "Ao legitimar o arbítrio por meio de alguma razão 'racional', o favorecido conscientemente engrandece a si e ao seu benfeitor, que por sua vez não vê, nessa era de hegemonia das razões, motivo para desmenti-lo". ${ }^{17}$ Por isso, as ideias existem fora do lugar. Brás Cubas sobrevoa todas as contradições em seu estado metafísico-físico de defuntoautor, mantendo seu local de senhor como biografia de seu tempo. Não desmente jamais a relação de poder que subjaz em sua narrativa. Prudêncio, por sua vez, integra o pensamento conservador sob a alcunha do favor. Procura jogar com o arbítrio de seus senhores, para - em sua condição de "homem livre", embora dependente dos caprichos ser reconhecido socialmente a despeito de sua condição negativa de "nem proprietário-nem proletário". No fundo, o pensamento conservador se mantém sob o olhar quase universal do senhor Brás Cubas, cujo fantasma se reproduz na ordem dos favores que lança homens livres como Prudêncio aos caprichos da violência que forja a matéria local.

\section{Sob o ponto de vista do oprimido}

Decerto, Prudêncio reproduz a ordem do senhor sem sê-lo. Mas disto surgem questões a partir dos processos de desenvolvimento deste personagem: como ele internaliza a lógica social do favor? Qual ordem de consciência resta em Prudêncio? Ou, com um olhar mais clínico, o que aconteceu entre o Prudêncio, moleque/escravo e o Prudêncio, adulto/homem-livre - período ausente na narrativa de Memórias? Questões que, talvez, auxiliem a afinar a natureza do pensamento conservador na periferia do capitalismo.

Aqui, convidamos o leitor para aproximar o exercício do crítico com a lição do pedagogo. Explorar, a partir do paradoxal romance de formação de Machado de Assis, as formas pelas quais a racionalidade conservadora se preserva. Sim, pois podemos ler Memórias póstumas como um romance de formação às avessas, ou melhor: o romance dos

\footnotetext{
16 SCHWARZ, Ao vencedor as batatas..., p. 18.

17 SCHWARZ, Ao vencedor as batatas..., p. 18.
} 
impasses de formação a partir das sutilezas ideológicas que se cristalizam na complexa rede de relações sociais apresentadas por Brás Cubas.

No entanto, para compreendermos ainda mais a figura de Prudêncio é preciso também que este seja liberto do olhar profundo do senhor. Isso não significa levantarmos uma faceta diversa de Prudêncio: ele continua a representar o pensamento conservador na medida mesma em que internaliza a ordem de violência que regula senhores e escravos. Mais ainda, ele se sustenta dos caprichos senhoriais enquanto partilha do jogo dos favores. Avançando ainda nessa linha, o que se pretende é compreender a gênese dessa faceta do homem-livre Prudêncio no momento mesmo em que não avança na luta de vida e morte contra seus senhores - como descrevia Hegel em sua tão comentada dialética do senhor e do escravo. ${ }^{18}$ A partir de sua condição social, sequer é possível extrair uma nova gramática do reconhecimento. Prudêncio vive o impasse da formação cuja linguagem é o favor: a tradução da gramática do senhor na língua dos homens livres.

Assim, para explorar ainda mais as possibilidades da gênese do pensamento conservador por nossas bandas, observemos Prudêncio entre os seus; notemos o personagem entre os oprimidos. Interessa aqui não mais a obediência aos pedidos de Nhonhô, mas o vergalho sobre seu subalterno. Que natureza de relações é esta que se cristaliza na ordem dos favores? Schwarz responde a isso em grande medida, sob o ponto de vista caprichoso do senhor. Mas podemos também notar a palavra que vem do corpo oprimido. E, nesse novo sentido, encontramos nas investigações de Paulo Freire uma complementaridade fundamental.

Decerto, é possível dizer que Freire acompanha em muitos sentidos a interpretação crítica de Schwarz sobre as relações de opressão, reconhecendo a pressão social que exerce o senhor que domina a periferia do capitalismo. No entanto, o olhar pedagógico procura apresentar as relações de poder e submissão através da gênese da consciência do oprimido. Freire aspira a esperança por encontrar entre Prudêncios uma fagulha de revolta. Para tanto, o autor procura dar vazão à gramática do oprimido no momento de maior tensão: “a existência de uma 'situação-limite' de opressão em que os homens se encontram mais imersos que emersos". ${ }^{19}$ Pois a preocupação do pedagogo reside aí: nas resistências contra uma educação crítica quando homens livres como Prudêncio estão tão imersos na sua formação pela opressão presente em seus braços, pernas, na capacidade de trabalhar, folgar, dormir - como nos descrevia Brás Cubas. Como arrancar esta pele de opressão?

A via pedagógica freiriana se abre pelos canais do diálogo. Operação intersubjetiva que avança nos processos de formação engendrados pelo encontro com as situações-limite,

${ }^{18}$ HEGEL, Fenomenologia do Espírito, vol. 1, pp. 126-134. Aliás, o que é a luta de vida e morte entre senhor e o escravo, quando aquele é um defunto? Não se desarma aqui a possibilidade dialética de sair desse estágio de dominação e escravidão quando a gramática hegemônica se coloca ironicamente nesse plano metafísico?

${ }^{19}$ FREIRE, Pedagogia do oprimido, p. 132. 
momento ímpar em que as contradições da realidade se apresentam aos sujeitos envolvidos no processo. A dialogicidade resulta das estruturas intersubjetivas de relação estabelecidas no enfrentamento de tais contradições, por vezes insolúveis conforme o contexto. Nesse sentido, o diálogo não é o ponto de partida. Para alcançar uma situação dialógica é necessário que os sujeitos em relação se reconheçam como tais. Do contrário, afirmar o diálogo sem as mediações necessárias para tal encontro apenas expressa o discurso do colonizador esclarecido e suas práticas de poder. De modo avesso, conforme Freire, o “diálogo é este encontro dos homens (sic), mediatizados pelo mundo, para pronunciá-lo, não se esgotando, portanto na relação eu-tu". ${ }^{20}$

No caso de Prudêncio, o diálogo não se estabelece nem em sua obediência ao pedido de Brás Cubas, nem tampouco com seu escravo. No primeiro caso, o encontro com seu senhor é mera relação "eu-tu" que reproduz o mundo senhorial sem qualquer ação reflexiva por parte do homem livre. Consequentemente, o favor é nexo identitário com o poder de dominação. No segundo caso, a ausência de diálogo é gritante: Prudêncio silencia seu escravo sob a ameaça do vergalho. Não há diálogo, apenas o silenciamento e a força bruta da barbárie senhorial.

Contrário a tal situação-limite, em que a pronúncia transformadora é silenciada pela paralisia do pensamento diante das contradições da realidade, Freire investe toda uma pedagogia que potencialize a ação-reflexiva dos sujeitos oprimidos. Para a dialogicidade é necessário o mundo pronunciado que "por sua vez, se volta problematizado aos sujeitos pronunciantes, a exigir deles novo pronunciar ${ }^{2} .{ }^{21} \mathrm{Na}$ lógica do favor, não há pronúncia, apenas troca de uma mesma realidade que atravessa todas as classes. A estratégia freiriana para tanto é fazer das "situações-limites" - as contradições da realidade - o principal disparador de processos dialogicizantes em que os sujeitos se reconhecem como pronunciantes de um mundo novo. De fato, "é necessário (...) que a situação em que estão não lhes apareça como algo fatal e intransponível, mas como uma situação desafiadora que apenas os limita". ${ }^{22}$ É do reconhecimento do limite que a consciência se lança - ou não, veremos aos desafios de superar as contradições da realidade.

É justamente esse passo que o pensamento conservador se mostra incapaz de realizar. Diante das contradições das situações-limite, a experiência passa pelo impasse de sua formação, seguindo dois caminhos possíveis: o avanço para o pensamento crítico, ou a irracionalidade do pensamento conservador. Afinal de contas, as situações-limite impõem à consciência o reconhecimento de que o fato vivenciado não é "algo que é", um "fato

\footnotetext{
${ }^{20}$ FREIRE, Pedagogia do oprimido, p. 109.

${ }^{21}$ FREIRE, Pedagogia do oprimido, p. 108.

22 FREIRE, Pedagogia do oprimido, p. 103.
} 
dado", mas algo que "está sendo", em processo. ${ }^{23}$ Em outras palavras, vivenciar situaçõeslimites retira a consciência do estado de imersão, oferece a ela outros pontos de vistas construídos pelo círculo cultural e possibilita, enfim, reconhecer a dinâmica dos fatos em seu processo e, com efeito, junto a seus impasses.

Este momento é central para Paulo Freire, uma vez que nele se consolidam as possibilidades de um salto qualitativo da consciência "ingênua" para a consciência "crítica". E, particularmente para nossos intuitos, é o território em que também passa a ser possível a estrutura do pensamento conservador. Há aqui a possibilidade de tudo ou nada nos processos pedagógicos. Desde este ponto, ficam abertas as vias ora para o diálogo, ora para a cristalização conservadora e seu consequente fechamento social às alteridades que escapam à ordem dos favores.

É como se Freire se deparasse de início com Prudêncios e Prudências para quem, de início, o mundo é este que lhes é oferecido: as relações de favor e do vergalho. "Manda quem pode, obedece quem tem juízo", diz o ditado popular. Imersos na opressão, subsistem como consciência "ingênua". Por esta expressão, Freire não descreve tais sujeitos como "tolos", tábulas rasas de experiências. Pelo contrário, lembra com Álvaro Vieira Pinto até certo sentimento de superioridade diante do mundo (ainda que submisso a ele), uma vez que tal consciência ingênua "se crê superior aos fatos, dominando-os de fora e, por isso, se julga livre para entende-los como melhor lhe agradar". ${ }^{24}$ Não são poucos os agregados que povoam as obras de Machado de Assis capazes de serem inscritos nesse estágio, a começar pelo filósofo Quincas Borba e toda a sua explicação ingênua do mundo por seu humanitarismo contrastante com a realidade do mundo em que vive.

Este estágio inicial do encontro com as consciências também pode se deparar com outro modo de consciência, oposto imediato, hegelianamente falando, à sua faceta ingênua. Trata-se da "consciência mágica", a qual "não se vê como superior aos fatos do mundo, mas os capta, emprestando-lhes um poder superior, que a domina de fora e a que tem, por isso mesmo, de submeter-se com docilidade". ${ }^{25}$ Em seu momento mágico, a consciência se relaciona com o mundo pela via fatalista. No conjunto de consciências presentes nesse momento inicial, sejam elas ingênuas ou mágicas, o modo como se relacionam com o mundo se dá pelo silenciamento de uma das partes da relação: seja o sujeito silenciado pela realidade, seja a realidade silenciada pelo sujeito. O mundo não é pronunciado por sujeitos pronunciantes, para explorar a gramática freiriana do diálogo. Por conseguinte, em ambos os estágios (ingênuo ou mágico) as relações se estabelecem como estáticas, cristalizadas e dadas.

\footnotetext{
${ }^{23}$ FREIRE, "O processo de alfabetização política - uma introdução" in FREIRE, Ação cultural para a liberdade e outros escritos, p. 74 (versão digital).

24 PINTO apud FREIRE, Educação como prática da liberdade, p. 105

${ }^{25}$ FREIRE, Educação como prática da liberdade, p. 105.
} 
Mas ainda aqui não está inscrita a possibilidade do pensamento conservador em toda a sua potência. É fato que o homem-livre Prudêncio pendula entre o mágico e o ingênuo, ora submetendo a realidade à sua imagem e semelhança (na submissão do escravo que ele perpetua), ora submetendo-se ao fatalismo das relações dadas da sociedade (na relação de favor com Nhonhô). Mas nestes dois estágios iniciais, insisto, não está cristalizado o pensamento conservador. Nesse momento ingênuo-mágico, a relação dos sujeitos com o mundo é "intransitiva". Falta o impasse, produto do encontro dessas consciências com a situação-limite, quando finalmente lhes é demandada a questão: o que faz̧er diante das contradições da realidade?

Eis o divisor de águas - e o momento mais delicado da proposta freiriana: quando se confere o salto mortal para a passagem ao pensamento crítico - morte simbólica das relações de opressão. Acrobacia arriscada e necessária que, na maior parte das vezes, pode resultar no acidente do pensamento conservador. Ora, a situação-limite exige do encontro intersubjetivo o sentido verdadeiro da palavra. Tal expressão não deve ser remetida ao sentido doutrinário do termo: como um aprendizado sobre a essência oculta dos termos em questão aguardando ser descoberta pelo exercício de pura hermenêutica de determinada doutrina. De acordo com Freire, não "há palavra verdadeira que não seja práxis. Daí dizer que a palavra verdadeira seja transformar o mundo". ${ }^{26}$ É neste vínculo da palavra com a práxis que reside a possibilidade do pensamento crítico pela via dialógica. Não é o falso humanismo do "ato de depositar ideias de um sujeito no outro, nem tampouco tornar-se simples troca de ideias a serem consumidas pelos permutantes". ${ }^{27}$ Fazer da palavra práxis é conferir-lhe circulação, constituindo espaços para sujeito dialógicos. Movimento que deve ser acompanhado atentamente.

Ora, "transformar o mundo" se estabelece junto à relação transitiva entre os sujeitos e destes com o próprio mundo. Portanto, Freire preocupa-se com o destino das mediações que preenchem este conjunto de relações transitivas. O desafio das situaçõeslimite deve consolidar a palavra transformadora mediante a ação junto à reflexão, sem as quais, permanece a condição oprimida e alienante em que se forja a consciência ingênua e mágica. Contudo, o processo para mobilizar ação e reflexão e, enfim, constituir um diálogo entre as partes diante da contradição em que vivem é, para Paulo Freire, um jogo em aberto: “Frente a este 'universo' de temas que dialeticamente se contradizem, os homens tomam suas posições também contraditórias, realizando tarefas em favor, uns, da manutenção das estruturas, outros, da mudança". ${ }^{28}$

\footnotetext{
${ }^{26}$ FREIRE, Pedagogia do oprimido, p. 107.

${ }^{27}$ FREIRE, Pedagogia do oprimido, p. 109.

${ }^{28}$ FREIRE, Pedagogia do oprimido, p. 129.
} 
Nesta abertura, reside a possibilidade do pensamento conservador em sua face mais avançada: a consciência fanática. Do impasse exposto pelas situações-limite, passa a ser possível não apenas a possibilidade do pensamento crítico, mas também toda a irracionalidade que alimenta o fanatismo através do aprofundamento das contradições e que afetam diretamente a esperança das relações transitivas da consciência sob a forma do diálogo. ${ }^{29}$ Sob esta forma, a dialogicidade se degenera sob a forma de polêmica: resta a discussão "entre sujeitos que não aspiram a comprometer-se com a pronúncia do mundo, nem a buscar a verdade, mas a impor a sua." 30

Desse modo, o pensamento conservador para Freire se dá como uma "patologia da ingenuidade", uma vez que, diante do impasse deflagrado pelas situações-limite, impede a consciência de vivenciar a palavra em circulação - pressuposto da ordem crítica. ${ }^{31} \mathrm{~A}$ consciência fanática passa da ingenuidade intransitiva para a irracionalidade que opera na relação adaptada com o mundo, reforçando estruturas de manutenção do status quo, próprias ao que Schwarz descreve nas relações de favor do homem-livre. Em outros termos, o pensamento conservador se revela patológico porque diante da contradição, sua ação é manter a ordem da opressão e as condições contraditórias que produzem as situações-limite. Não se trata de mero regresso ao estágio ingênuo e mágico, pois até então, as consciências estavam imersas na opressão, vivida como um fato dado. Na gramática do favor em que subsiste o pensamento conservador, a consciência apenas emerge da sua condição de oprimida, sem que se veja inserida na realidade contraditória que se vai desvelando. Daí, há uma diferença qualitativa do fanático diante do ingênuo. Este se mantinha imerso na opressão, ao passo que aquele consegue emergir desta condição. $O$ caráter patológico está no fato de que a emersão resulta na diluição de sua condição diante da realidade. Disso, valendo-nos da análise de Schwarz, o principal sintoma está nas relações pendulares próprias à ordem do favor. Não confere o passo fundamental que é se refletir como inserida na realidade contraditória. Visão crítica que permite, de acordo com Freire, uma consciência histórica e, consequentemente, transformadora. ${ }^{32} \mathrm{O}$ favor, por sua vez, é a relação das acomodações que alimentam fanatismos, patologias que surgem dos impasses da formação.

\footnotetext{
${ }^{29}$ FREIRE, Educação como prática da liberdade, p. 51.

${ }^{30}$ FREIRE, Pedagogia do oprimido, p. 109.

${ }^{31}$ FREIRE, Educaşão como prática da liberdade, p. 105.

32 "Da imersão em que se achavam, emergem, capacitando-se para se inserirem na realidade que se vai desvelando. (...) Desta maneira, a inserção é um estado maior que emersão e resulta da conscientização da situação. É a própria consciência histórica" (FREIRE, Pedagogia do oprimido, p. 141).
} 


\section{Intervenções}

Daqui, encaminho para algumas conclusões, tendo em vista as intervenções possíveis. Como vimos, intervir na realidade do pensamento conservador é tarefa difícil que exige habilidade de esgrimista sutil. Apontá-lo diretamente como tal, com a tentativa de apresentar ao conservador de maneira clara e distinta a realidade contraditória da qual emerge pode gerar o reforço patológico do fanatismo. Distante do diálogo, e propenso à polêmica, o pensamento conservador se estrutura como guardião da ordem do favor da qual se beneficia.

Percebemos com Schwarz, por um lado, a constituição do pensamento conservador a partir da narrativa dos senhores. O homem-livre como ideia fora do lugar e que reproduz a violência da base produtiva nacional escravista. Por outro lado, com Freire possibilitamos o ponto de vista do pensamento conservador que emerge entre os oprimidos. Com efeito, o exercício de intervenção possível deve levar em conta a pseudo-formação do pensamento conservador como efeito dessas duas linhas que entrecruzam na sociedade dos homens livres. Submetido ao olhar do senhor ou imerso na condição oprimida, o homem livre encontra na relação de favor a estratégia de sustentar-se numa ordem social de extrema violência.

O personagem Prudêncio de Memórias póstumas... se mostra um caso exemplar para isso. Ele ocupa o ponto médio entre senhores e escravos, pendulando entre uma e outra posição social, dependendo do ponto de vista que se assume na periferia. Aparência sobre aparência, este agregado vive as contradições de não ser nem proprietário, nem proletário. Deste ponto de vista das categorias clássicas da sociologia moderna, o homem livre estaria fora do jogo social. No entanto, entra nele por outro campo: pelo campo de favores que ilumina a face senhorial em seus caprichos. A lógica que opera em Prudêncio atravessa o tempo histórico e encontra nos tempos de massificação uma possível manifestação de seu caráter conservador. Em Freire, é no fanatismo que reencontramos Prudêncio em toda a sua potência.

Ganhamos aqui a possibilidade de analisar a ordem de contradições local em uma estrutura lógica das origens coloniais. Freire está atento aos riscos que os processos de conscientização trazem em nossa realidade nacional:

não é possível ou é quase impossível viver uma sociedade um clima histórico-cultural como este, sem que se desencadeassem forças intensamente emocionais. São os resultados dos próprios embates das contradições. Este clima emocional, alongado em irracionalismos, é que gerava, alimentava e fazia crescer as posições sectárias. Nos que pretendiam deter a História, para, assim, manter seus privilégios. Nos que pretendiam 
antecipar a História, para, assim, "acabar" com os privilégios. Ambos minimizando o homem. Ambos trazendo sua colaboração à massificação, à demissão do homem brasileiro, que apenas iniciava sua admissão à categoria de povo. ${ }^{33}$

O irracionalismo fanático do conservador irrompe no momento em que a situaçãolimite vem à tona. Presente na sociedade massificada, a ordem dos favores passa a ser chave de disputa. Os privilégios dos outros são alvos da caça fanática, ao passo que os próprios privilégios devem ser mantidos. Efeito da ordem política baseada nas relações de favor.

Diante de tal realidade aquecida de emoções temperadas por contradições candentes, antevemos com Schwarz e Freire, duas possibilidades de intervenção, cada qual empunhando as armas possíveis de suas críticas.

Da perspectiva estético-política, Schwarz compreende o jogo crítico modelado por Machado de Assis (bem como outros escritores nossos contemporâneos) tracejando a forma estética capaz de absorver as contradições históricas desde o ponto de vista periférico. Jogo de sobreposição de formas próprias da relação com a matéria social em que dormita a História. ${ }^{34}$ A lição estética de Machado, que aprendemos com Schwarz, é a adoção de estratégias que buscam atingir o centro desde a periferia: seria em vão a adoção da forma literária moderna - por mais vanguardista que o seja - de maneira direta na ordem periférica. A potência está em tratar indiretamente a ordem das relações, apresentando no jogo formal o alcance da violência nelas implícita. Daí todo o cinismo dos personagens machadianos, acompanhados por Schwarz nos detalhes. Machado procura assim desativar o dispositivo irracional das polêmicas que povoam o ideário nacional fora do lugar. É na composição de formas que Machado deixa sua mensagem e seu possível diálogo com a realidade e suas contradições.

Paulo Freire assume outras armas críticas, no campo pedagógico do problema. Talvez por assumir um ponto de partida diverso ao de Schwarz - a matéria dos oprimidos - compreende o processo de conscientização como alvo de suas investidas. Toda a dificuldade está em dois pontos. Primeiramente, como desativar desses processos pedagógicos a ordem colonizadora, tão frequente nas questões educativas? Mas também, como evitar o reforço conservador que inviabiliza a autonomia do pensamento crítico. Freire não tem dúvidas de que o princípio está na exposição das situações-limites. É na contradição que a situação de opressão expressa sua força, ainda que sob o preço de emergir o pensamento conservador na tentativa de manter a ordem social que o sustenta.

${ }^{33}$ FREIRE, Educação como prática da liberdade, p. 55.

34 SCHWARZ, Ao vencedor as batatas..., p. 31. 
Lembremos, no entanto, que também desta situação-limite advém o pensamento crítico. Eis a aposta freiriana por excelência.

Em tempos de contrarrevolução, os exemplos de Freire e Schwarz oferecem contrapontos interessantes. Recuperamos com eles duas matérias ricas daquilo que se chamou "sistema de formação". Um olhar para nós mesmos enquanto periféricos no mundo. Possibilidade de crítica diante das contradições que forjam nossas condições, o enlace entre educação e literatura, essenciais para a palavra que pronuncia o mundo, passa a ser explosivo perigoso contra a ordem da violência e do silêncio que alimentam o pensamento conservador.

\section{IMPASSES ON SOCIAL FORMATION: CONSERVATIVE THINKING IN SCHWARZ AND FREIRE}

Abstract: This paper intends to describe genesis of conservative thinking as a phenomenon of social formation. Then, literary criticism and education present themselves as important sources to analysis on the system of national formation. The Roberto Schwarz' essay "As ideias fora do lugar" ["Ideas out of own place"] presents the question of conservative thinking. The author analyses the genesis of national conservatism by the free labor, which is very important to Machado de Assis' works. It represents the submission to the order of the favors and the social composition of the clientelism submitted to the ruling classes. Moreover, Paulo Freire's pedagogy underlines the Conservative thinking from the perspective of the oppressed people. From the moment when real contradictions appear to the oppressed people, critical consciousness can emerge as well as fanatical consciousness as sustained by the power of the silence and violence proper to the Conservatism. Therefore, Conservative thinking reflects the impasses on social formation under the perspective of the master or by the condition of oppressed. At the end, we have a final question: how to intervene from these aesthetical-politics and pedagogical diagnosis as described by Schwarz and Freire respectively?

Key-words: Conservatism, System of Social Formation, Opressed people, Roberto Schwarz, Paulo Freire.

\section{Referências Bibliográfias}

ASSIS, José Maria Machado de, Memórias Póstumas de Brás Cubas/Quincas Borba, São Paulo: Scipione, 1994.

ARANTES, Paulo Eduardo. Sentimento da dialética na experiência intelectual brasileira: dialética e dualidade segundo Antonio Candido e Roberto Schwarz, Rio de Janeiro: Paz e Terra, 1992.

CANDIDO, Antonio. Formação da literatura brasileira: momentos decisivos (1750-1880), Vol. Único, São Paulo: Editora Ouro Sobre Azul, 2014. 
CHAUI, Marilena de Souza, Brasil: mito fundador e sociedade autoritária, São Paulo: Fundação Perseu Abramo, 2000.

FERNANDES, Florestan. A revolução burguesa no Brasil, Rio de Janeiro: Ed. Globo, 2015.

FREIRE, Paulo. Educação como prática da liberdade, Rio de Janeiro: Paz e Terra, 1967. Ação cultural para a liberdade e outros escritos, Rio de Janeiro: Paz e Terra, $5^{a}$ edição, 1981. . Pedagogia do oprimido, Rio de Janeiro: Paz e terra, 2015.

FURTADO, Celso. Formação econômica do Brasil, São Paulo: Cia das Letras, 2007.

HEGEL, Georg Wilhelm Friedrich. Fenomenologia do Espirito, 2 vol., trad. Paulo Meneses, Petrópolis, RJ: Vozes, $2^{\mathrm{a}}$ ed., 1992.

HOLLANDA, Sérgio Buarque. Raízes do Brasil, São Paulo: Cia. das Letras, 2015.

LAMPEDUSA, Giuseppe Tomasi di. O leopardo, Lisboa: Dom Quixote, 2014.

MARCUSE, Herbert. O homem unidimensional: Estudos da ideologia da sociedade industrial avançada, trad. Robespierre de Oliveira et al., São Paulo: Edipro, 2015.

OLIVEIRA, Francisco de. Crítica à razãa dualista: o ornitorrinco, São Paulo: Boitempo, 2003.

PRADO JR. Caio. Formação do Brasil contemporâneo, São Paulo: Cia. das Letras, 2011.

SCHWARZ, Roberto. Ao vencedor as batatas: forma social e processo social nos inicios do romance brasileiro, São Paulo: Ed. Duas Cidades, Ed. 34, 2000.

Um mestre na periferia do capitalismo: Machado de Assis, São Paulo: Ed. Duas Cidades, Ed. 34, 2000.

SOUZA, Jessé. A Tolice da inteligência no Brasil: ou como o país se deixa manipular pela elite, São Paulo: LeYa, 2015. 